\title{
Chemical composition of tempeh from soybean cultivars specially developed for human consumption
}

\author{
Composição química de tempeh de cultivares de soja especialmente desenvolvidas para \\ o consumo humano
}

\author{
Ana Carla Furlan BAVIA ${ }^{1}$, Carlos Eduardo da SILVA ${ }^{1}$, Márcia Pires FERREIRA², Rodrigo SANTOS LEITE ${ }^{1}$, \\ José Marcos Gontijo MANDARINO ${ }^{1}$, Mercedes Concórdia CARRÃO-PANIZZI ${ }^{3 *}$
}

\begin{abstract}
Tempeh is a food obtained by fermentation of soybean grains by the fungus Rizophus oligosporus. It is a traditional Indonesian food that presents benefits for human health protecting against diarrhea and chronic diseases. Tempeh processing includes dehulling, cooking, inoculation, and fermentation. In this study, chemical characteristics of tempeh prepared with soybean cultivars specially developed for human consumption (BRS 216, BRS 232, BRS 257, and BRS 267) were investigated. Soybean grains and tempeh obtained from these cultivars were analyzed for oil, protein, antinutrional factors, and isoflavone content. Cultivar BRS 216 presented the highest protein content in the grains (36.81\%) and in tempeh (51.99\%). On average, the protein content in tempeh increased $16 \%$ in relation to that of soybean grains. Isoflavone content was higher in the grains than in tempeh with significant differences among the cultivars. However, the aglycones content increased about $50 \%$

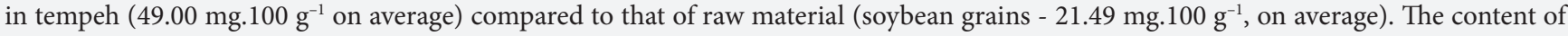
Kunitz trypsin inhibitor (KSTI) reduced $83 \%$ in tempeh, on average, as compared to the value found in the grains. Phytic acid content was similar in both tempeh and the grains.
\end{abstract}

Keywords: soybean; functional food; isoflavones; protein; antinutritional factors.

\section{Resumo}

O tempeh é um alimento obtido por meio da fermentação dos grãos de soja pelo fungo Rizophusoligosporus. É um alimento tradicional da Indonésia que apresenta benefícios para a saúde humana, protegendo contra a diarréia e doenças crônicas. O processamento de tempeh inclui descasque, cozimento, inoculação e fermentação. Nesse estudo, as características químicas de tempeh produzido com cultivares de soja especialmente desenvolvidas para alimentação humana, BRS 216, BRS 232, BRS 257 e BRS 267 foram investigadas. Os grãos das cultivares e os tempehs foram analisados quanto aos teores de óleo e proteína, fatores antinutricionais e teor de isoflavonas. A cultivar BRS 216 apresentou o maior teor de proteína no tempeh $(51,99 \%)$ e nos grãos (36,81\%). Em média, no tempeh, o teor de proteína aumentou $16 \%$. O teor total de isoflavonas foi maior nos grãos do que nos tempehs, com diferenças significativas entre as cultivares. O conteúdo de isoflavonas agliconas aumentou em média cerca de 50\% nos tempehs (49,00 mg.100 g-1 em média), quando comparados com a matéria-prima grãos de soja (21,49 mg. $100 \mathrm{~g}^{-1}$ em média). O conteúdo de inibidor de tripsina de Kunitz (KSTI) apresentou uma redução de $83 \%$ nos tempehs em relação ao conteúdo observado nos grãos. Os teores de ácido fítico nos tempehs e nos grãos de soja foram semelhantes.

Palavras-chave: soja; alimento funcional; isoflavonas; proteína; fatores antinutricionais.

\section{Introduction}

Innovations in the technology of food processing improve quality of soybean products. By genetic breeding, special quality characteristics of soybean are improved (LIU, 1997; CARRÃOPANIZZI et al., 2009a). Soybean foods can be fermented, which in general are traditional oriental foods such as miso, shoyu, tempeh, and natto, or non-fermented, among which the most popular are soymilk and tofu (VILLARES et al., 2011).

Tempeh is a traditional fermented soybean food from Indonesia. It is consumed fried, boiled, steamed, or roasted, and thanks to the Dutch in 1948, it became popular in Europe, where it has been consumed by vegetarians and non-vegetarians to reduce meat consumption (KARYADI, 2001). Its pleasant, mushroom-like aroma and delicious nutty flavor makes it an excellent alternative to meat, fish, and poultry dishes (PRIDE, 1984). It is a product that not only adds variety to the diet, but also enhances it nutritionally.

During fermentation, there are nutritional and chemical changes that improve taste, flavor, and functional properties

Received 6/5/2011

Accepted 21/6/2012 (005263)

${ }^{1}$ Empresa Brasileira de Pesquisa Agropecuária - Embrapa Soybean, Londrina, PR, Brazil

2 Universidade Instituto Filadélfia - UNIFIL, Londrina, PR, Brazil

${ }^{3}$ Empresa Brasileira de Pesquisa Agropecuária - Embrapa Wheat, Rod. BR 285, Km 294, CP 451, CEP 99001-970, Passo Fundo, RS, Brazil,

e-mail:mercedes@cnpt.embrapa.br

${ }^{*}$ Corresponding author 
of the products (NOUT; KIERS, 2004). Enzymes produced during fermentation affect protein, fat, and carbohydrates. The complex sugars stachyose and raffinose, which cause flatulence, are broken down into digestible sugars. During fermentation, the fungus produces the enzyme phytase that mobilizes the phytic acid improving bioavailability of minerals. Fermentation also promotes the synthesis of B group vitamins (HERMANA; MAHMUD; KARYADI, 2001) improving flavor, nutritional, chemical and functional properties of the products (NOUT; KIERS, 2004).

Isoflavones are important biological active compounds that confer antioxidant activity to soybeans with health benefits for humans. Due to its antioxidant effects and other nutritional characteristics of tempeh, Nout and Kiers (2004) suggested that in addition to the traditional tempeh food, it could also be processed into powdered form to be used as a food ingredient of health foods, mainly to control diarrhea among children (SUDGIBIA, 2001)

During tempeh fermentation, the enzyme $\beta$-glycosidase hydrolyses the $\beta$-glycosides forming the aglycones, which is the readily available form. Carrão-Panizzi and Bordignon (2000) reported that soybean cultivars show a significant genetic variability for $\beta$-glucosidase activity. Genetic differences and environmental effects for isoflavone contents in Brazilian soybean cultivars were also investigated by Carrão-Panizzi et al. 2009b. Their results suggest that the choice of cultivars with better chemical composition will allow processing of high quality soy foods for human consumption. The present study had the objective to verify changes in the content of protein, lipids, ashes, isoflavones, and antinutrional factors in tempeh processed with different soybean cultivars specially developed for human consumption.

\section{Materials e methods}

Grains of soybean cultivars BRS 216, BRS 232, BRS 257, and BRS 267, produced at the experimental field of the National Soybean Research Center, in Londrina, Paraná State, Brazil were used to process tempeh. BRS 232 is a grain type cultivar (cv), BRS 216 is a small seed cv. for natto and sprout; BRS 257 is a null lipoxygenase cv.; and BRS 267 is a large seed cv. for tofu and edamame (CARRÃO-PANIZZI et al., 2009a). The freeze-dried inoculums of the fungus Rhizopus microsporus var. Oligosporus obtained from INTSOY (International Soybean Program, from the University of Illinois, USA) were used for preparation of tempeh.

\subsection{Preparation of tempeh}

Tempeh was prepared according to traditional method (WEI, 1991). Clean soybean grains were dehulled, and the cotyledons were boiled in water for 10 minutes. The hot water was drained, and the cotyledons were soaked in water for 17 hours at room temperature. The hydration water was discharged, and the hydrated grains were cooked in boiling water for 30 minutes. After cooking, the hot water was drained again, and the cooked soybean cotyledons were cooled down to room temperature. The cooked and cooled cotyledons were inoculated with spores of the fungus $R$. oligosporus and were packed in polypropylene bags with small and equidistant perforations and were incubated at $32^{\circ} \mathrm{C}$ for 26 hours to obtain the tempehs. Fresh tempehs were freeze-dried in a freeze drier (Liotop model L 110) and milled in a refrigerate mill (Tecnal model TE 631/2). Samples of freeze-dried milled tempeh were stored in glass containers for further chemical analysis.

\subsection{Chemical composition}

Samples of whole grains and freeze-dried tempehs were ground into fine particles and analyzed for moisture, protein, lipid and ash (in dry basis) according to the Food Analysis of Institute Adolfo Lutz (BRASIL, 2005).

\subsection{Isoflavone analysis}

\section{Isoflavone extraction}

The extraction of isoflavones was performed according to the method described by Carrão-Panizzi, Favoni and Kikuchi (2002). Samples of $100 \mathrm{mg}$ of freeze-dried tempeh and whole grains ground in fine particles that were defatted with $\mathrm{N}$-hexane (HPLC grade) at room temperature under constant shake for 8 hours were added to test tubes with lid. Next, $4.0 \mathrm{~mL}$ of the solvent extraction (70:30 ethanol: water solution containing $0.1 \% \mathrm{~V} / \mathrm{V}$ of glacial acetic acid) were added. The extraction was performed for one hour with shaking every 15 minutes in a "Vortex" tube shaker. The tubes containing the samples and the extraction solution were placed into an ultrasonic bath for 30 minutes at room temperature; $1.5 \mathrm{~mL}$ of the supernatant was transferred to $2.0 \mathrm{~mL}$ "Ependorff" tubes that were centrifuged in an Eppendorff microcentrifuge (model $5417 \mathrm{R}$ ) at 21,000 g for 15 minutes at $4{ }^{\circ} \mathrm{C}$. The supernatants were filtered through a $45 \mu \mathrm{m}$ Millipore membrane and transferred to a HPLC autosampler injection vials. $20 \mu \mathrm{L}$ of the extracts (injection volume) were used for profile analysis and quantification of the isoflavones in tempeh and in grains.

\section{Separation and quantification of isoflavones}

Separation and quantification of the isoflavones were conducted according to the method proposed by Berhow (2002) in a high pressure liquid chromatographer (HPLC - Waters), solvent pump model 600 equipped with an autosampler injector (Waters, model 717 plus). The isoflavones were eluted in a reverse phase ODS-AM C18 column $(4.6 \mathrm{~mm} \times 250 \mathrm{~mm}$ -YMC Pack) and $5 \mu \mathrm{m}$ particles. For separation, a linear binary gradient system with two mobile phases was used: 1 ) methanol with $0.025 \%$ trifluoroacetic acid (TFA) (solvent A); and 2) distilled deionized ultrapure water with $0,025 \%$ de TFA (solvent B). The initial gradient system condition consisted of $20 \%$ methanol acidified with $0.025 \%$ trifluoracetic acid ( $\mathrm{pH} 3.0$ ) and $80 \% \mathrm{H}_{2} \mathrm{O}$ acidified with $0.025 \%$ trifluoracetic acid ( $\mathrm{pH} 3.0$ ). The proportion of $90 \%$ methanol and $10 \% \mathrm{H}_{2} \mathrm{O}$ was reached in 35 minutes of elution. The gradient proportion of $100 \%$ methanol was reached at 40 minutes, remaining in this condition for 5 minutes for column cleaning, and then it returned to the initial condition of $20 \%$ methanol and $80 \% \mathrm{H}_{2} \mathrm{O}$ in 20 minutes. The final elution time was 60 minutes. The solvent flow rate was 
$1 \mathrm{~mL} \cdot \mathrm{min}^{-1}$, and the temperature of the column was maintained constant at $25^{\circ} \mathrm{C}$.

The photodiode array detector (Waters, model 996) adjusted to $254 \mathrm{~nm}$ was used for the detection of the isoflavones. For the identification of the correspondents peaks of each isoflavone, it was used standards (Sigma) of the 12 forms of isoflavones (glycosides, glycitins, acetyls, malonyls e aglycons) solubilized in methanol (HPLC grade) at the following concentrations: $0.00625 \mathrm{mg} \cdot \mathrm{mL}^{-1} ; 0.0125 \mathrm{mg} \cdot \mathrm{mL}^{-1} ; 0.0250 \mathrm{mg} \cdot \mathrm{mL}^{-1} ; 0.0500 \mathrm{mg}$. $\mathrm{mL}^{-1}$, and $0.1000 \mathrm{mg} \cdot \mathrm{mL}^{-1}$, and standard curves were established for each form. These concentrations were used after the limit of detection (LD) and the limit of quantification (LQ) of the equipment were obtained with standards of daidzein and genistein. The LD was $0.0005 \mathrm{mg} \cdot \mathrm{mL}^{-1}$, and the LQ was $0.0015 \mathrm{mg} \cdot \mathrm{mL}^{-1}$. The peaks identified as the retention time standards of each isoflavone were: daidzin $=19.75$ minutes, glycitin $=20.40$ minutes, genistin $=22.75$ minutes, malonyl-daidzin $=24.60$ minutes, malonyl-glycitin $=25.20$ minutes, malonyl-genistin $=27$ minutes, acethyldaizin $=26$ minutes, acethyl-glycitin $=26.60$ minutes, acethyl-genistin $=28.80$ minutes, daizein $=29.00$ minutes, glycitein $=29.50$ minutes, and genistein $=31.60$ minutes .

The content of the isoflavones was expressed in $\mathrm{mg} .100 \mathrm{~g}^{-1}$ of samples in dry basis. The separated and quantified isoflavones were $\beta$-glycosides conjugates (daidzin, glycitin, and genistin), the derivates malonyl- $\beta$-glycosides (malonyldaidzin, malonylglycitin and malonylgenistin), and the aglycons (daidzein, glycitein, and genistein). The contents (mg.100 g $\mathrm{g}^{-1}$ ) of malonylglycosides, $\beta$-glycosides, aglycons, and total isoflavones were expressed as aglycons in soybean grains and in tempeh after the conversion of each isoflavone form using a correcting factor calculated by the division of the molecular weight of each isoflavone for the corresponding aglycon form (TONGTONG et al. 1998; KLUMP et al. 2001).

\subsection{Kunitz trypsin inhibitor (KSTI)}

Quantification of the Kunitz Trypsin Inhibitor (KSTI) content was made according to Kakade et al. (1974) with modifications of Hamerstrand, Black e Glover (1981).

\section{Sample preparation}

In Erlenmeyers of $250 \mathrm{~mL}$, it was added five grams of tempeh and grain samples ground into fine particles in a refrigerated mill. Next, the samples were defatted with $50 \mathrm{~mL}$ of N-hexane under constant shaking on an orbital shaker table (Tecnal, model TE 140) for 16 hours at room temperature. After this procedure, the $\mathrm{N}$-hexane was drained, and the samples were transferred to Petri dishes under air flushing to allow any residual solvent to evaporate. The defatted samples were passed through a 100 mesh sieve, and the fine flour obtained was used for the trypsin inhibitor extraction.

\section{Extraction of the trypsin inhibitor}

Trypsin inhibitor extraction was accomplished with three replicates for each sample. In $125 \mathrm{~mL}$ Erlenmeyers, $1.0 \mathrm{~g}$ of defatted milled samples was extracted with $50 \mathrm{~mL}$ of $0.01 \mathrm{~N}$ sodium hydroxide solution at room temperature under constant shaking for three hours. The solution $\mathrm{pH}$ was adjusted to 9.2 by using a $\mathrm{pH}$ meter, and $2.0 \mathrm{~mL}$ aliquots were taken. These aliquots were transferred to $100 \mathrm{~mL}$ volumetric flasks, and the volume was completed with ultrapure water. These diluted solutions were used for Kunitz trypsin inhibitor (KSTI) quantification.

\section{Reagents preparation for KSTI determination}

BAPA (benzoil-DL-arginine-p-nitroanilide) solution was prepared by weighting $0.080 \mathrm{~g}$ of BAPA dissolved in $2.0 \mathrm{~mL}$ of dimethil sulfoxide and transferred to a $200 \mathrm{~mL}$ volumetric flask completed with a pre-heated $\left(37^{\circ} \mathrm{C}\right)$ Trizma buffer solution. This solution is stable for only 4 hours.

Trizma buffer was prepared by weighting $1.21 \mathrm{~g}$ of Trizma and $0.59 \mathrm{~g}$ of dihydrate calcium chloride $\left(\mathrm{CaCl} 2.2 \mathrm{H}_{2} \mathrm{O}\right)$ and dissolved in $180 \mathrm{~mL}$ of ultrapure water, and the $\mathrm{pH}$ was adjusted to 8.2 with $1 \mathrm{~N}$ hydrochloride acid. This solution was transferred to a $200 \mathrm{~mL}$ volumetric flask, and the volume was completed with ultrapure water. This solution is stable for only 8 hours.

Trypsin inhibitor solution was prepared by weighting $0.0020 \mathrm{~g}$ of trypsin and dissolved with $100 \mathrm{~mL}$ of $0.001 \mathrm{~N}$ hydrochloride acid solution.

\section{Kunitz trypsin inhibitor determination}

Trypsin inhibitor quantification was accomplished in three replicates. After extraction, three aliquots of the diluted extract were taken for each replicate. Five test tubes were prepared for analysis: three for quantification of the trypsin inhibitor in the samples extracts (tubes 1, 2, and 3), one for the blank (4), and one for the trypsin standard (5).

Two $\mathrm{mL}$ of the diluted extract were added to tubes $1,2,3$, and 4 , and $2.0 \mathrm{~mL}$ of ultrapure water were added to tube 5 . Next, $2.0 \mathrm{~mL}$ of trypsin inhibitor solution were added to tubes 1,2 , 3 , and 5 . The tubes were homogenized and placed in a water bath at $37^{\circ} \mathrm{C}$ for exactly 10 minutes. Then, $5.0 \mathrm{~mL}$ of pre-heated $\left(37^{\circ} \mathrm{C}\right) \mathrm{BAPA}$ solution were added to all tubes. Each tube was homogenized and placed back in the water bath immediately for another 10 minutes interval.

After that time, $1.0 \mathrm{~mL}$ of $30 \%$ acetic acid solution was added to all tubes and they were homogenized again. Then, $2.0 \mathrm{~mL}$ of trypsin solution were added to tube 4 (blank). The solutions were filtrated through a Whatman $n^{\circ} 3$ paper filter, and their measurements of absorbance were performed in a spectrophotometer adjusted to $410 \mathrm{~nm}$ wavelength.

Observation: For complete homogenization, it is recommended 30 second intervals between each addition of solutions in the tubes.

The Kunitz trypsin inhibitor content (mgTI.g ${ }^{-1}$ sample) was calculated according to the following formula 1 :

$m g T I . g^{-1}=\frac{\text { Standard tube absorption }- \text { sample tube absorption } \times 2,500}{38 \times \text { sample weight }(\mathrm{g})}$ 


\subsection{Phytic acid content}

The phytic acid content in the soybean grains and in tempehs was determined according to the method proposed by Latta and Eskin (1980) modified by Bordignon, Silva and Carrão-Panizzi (2000).

\section{Phytic acid extraction}

For phytic acid extraction, one gram of tempehs and grain samples ground to fine particles in a mill were weighed and transferred to $125 \mathrm{~mL}$ Erlenmeyers, and $10 \mathrm{~mL}$ of $0.8 \mathrm{M}$ hydrochloric acid were added. The samples were constantly shaken in an orbital shaker table (Tecnal, model TE 140) for 2 hours at $250 \mathrm{rpm}$, followed by centrifugation at 10,000 g for 10 minutes. The supernatant was used for phytic acid separation through an ion exchange column.

\section{Phytic acid separation}

For phytic acid separation, an ion exchange column prepared with $0.5 \mathrm{~g}$ of Dowex resin (type $1 \mathrm{X} 4-50$ ) and built over a $1 \mathrm{~cm}$ glass wool layer was used. The columns were washed with ultrapure water and equilibrate with $10 \mathrm{~mL}$ of $0.7 \mathrm{M}$ sodium chloride $(\mathrm{NaCl})$ solution. Two $\mathrm{mL}$ of the supernatant solution previously obtained in the extraction step was slowly applied to the top of the column. Undesirable cations were eluted from the column by adding $10 \mathrm{~mL}$ of $0.1 \mathrm{M}$ sodium chloride $(\mathrm{NaCl})$ solution. Phytic acid was then eluted from the column with $10 \mathrm{~mL}$ of $0.7 \mathrm{M}$ sodium chloride $(\mathrm{NaCl})$ solution and collected for spectrophotometric determination.

\section{Spectrophotometric determination of the phytic acid}

For phytic acid spectrophotometric determination, a calibration curve prepared with dodecassodium phytate solution (35.29 mg of phytic acid, $85 \%$ purity, in $100 \mathrm{~mL}$ ultrapure water) was used. Fifteen $\mathrm{mL}$ of this primary solution were diluted in volumetric flask to a $100 \mathrm{~mL}$ final volume with ultrapure water. From this secondary solution, different volume aliquots between 0.1 and $0.5 \mathrm{~mL}$ were taken. Aliquots were transferred to test tubes and diluted to a $3 \mathrm{~mL}$ final volume with ultrapure water. Next, $1 \mathrm{~mL}$ of Wade Reagent ( $0.03 \mathrm{~g}$ monohydrate ferric chloride $(\mathrm{FeCl} 3 . \mathrm{H} 2 \mathrm{O})$ and $0.30 \mathrm{~g}$ of sulfosalicilic acid, diluted in $100 \mathrm{~mL}$ ultrapure water were added to each tube. Phytic acid concentration was determined in a spectrophotometer adjusted to $500 \mathrm{~nm}$ wavelength. In order to verify the Wade Reagent stability, its pure solution absorbance should be between 0.490 and $0.530 \mathrm{AU}$.

\subsection{Statistical analysis}

Exploratory data analyses were performed to verify homogeneity of variance, which were arranged in a complete randomized design with 2 treatments (soybean grains and tempeh) and four cultivars (BRS 216, BRS 232, BRS 257, and BRS 267), with three replicates. The data were submitted to analysis of variance (ANOVA), and the means were compared by the Tukey test at $5 \%$ probability. The data was analyzed by SAS - Statistical Analysis System (STATISTICAL..., 2001) and Sanest (ZONTA; MACHADO; SILVEIRA JÚNIOR, 1982).

\section{Results and discussion}

The protein contents in both the samples of soybean grains and samples of tempeh were significantly different $(\mathrm{P} \leq 0.05)$ between the cultivars. Cultivar BRS 216 had the highest protein content in grains (36.81\%), and in tempeh (51.99\%) (Table 1). The high protein content of this cultivar was corroborated by Carrão-Panizzi et al. (2009a). Wang (1986) and Vaidehi and Rathnamani (1990) reported protein content for tempeh of $48 \%$.

Protein content increased in tempeh (Table 1) due to the cooking and fermentation steps during tempeh processing, which favor losses of soluble substances (mineral and sugars) from soybean grains. Similar result was described by Vaidehi and Rathnamani (1990), who observed an increase in protein content of $14.35 \%$ higher in tempeh than in whole grains. Ferreira et al. (2011) working with Brazilian soybean cultivars (BR-36 e IAS 5) observed, on average, an increase of $21 \%$ in tempeh as compared to cotyledons. Since tempeh is prepared with dehulled soybean, increases in concentrations of the nutrients are expected.

The oil content observed in the soybean grains and in tempeh samples (Table 1$)$ were also different $(P \leq 0.05)$. The grain samples presented an average oil content similar to that normally observed for soybean (LIU, 1997), while the oil content in the tempehs obtained from all cultivars decreased, except for BRS 257 (Table 1). The average oil content in tempeh was reported as being 25.04\% (LEITAO; MENEZES; TANGO, 1967).

The mineral (ash) content in the samples of grains and tempeh did not differ $(\mathrm{P} \leq 0.05)$. In the soybean grains, the average value for all cultivars was $6.13 \%$ (Table 1 ), higher

Table 1. Protein, oil, and ash content ( $\left.\mathrm{g} .100 \mathrm{~g}^{-1}\right)$ based on dry weight in soybean grains and in tempeh prepared with different cultivars specially developed for human consumption.

\begin{tabular}{|c|c|c|c|c|c|c|}
\hline \multirow{2}{*}{ Cultivars } & \multicolumn{2}{|c|}{ Ash } & \multicolumn{2}{|c|}{ Protein } & \multicolumn{2}{|c|}{ Oil } \\
\hline & Soybean grains & Tempeh & Soybean grains & Tempeh & Soybean grains & Tempeh \\
\hline BRS 216 & $5.66( \pm 0.40)^{\mathrm{Ba}}$ & $4.06( \pm 0.5 \mathrm{~B})^{\mathrm{b}}$ & $36.81( \pm 0.80)^{\mathrm{Ab}}$ & $51.99( \pm 0.09)^{\mathrm{Aa}}$ & $21.98( \pm 1.25)^{\mathrm{Ba}}$ & $20.95( \pm 0.48)^{\mathrm{B}}$ \\
\hline BRS 232 & $6.17( \pm 0.09)^{\mathrm{Aa}}$ & $5.22( \pm 0.08)^{\mathrm{Ab}}$ & $34.73( \pm 1.04)^{\mathrm{Bb}}$ & $41.62( \pm 0.55)^{\mathrm{Da}}$ & $23.99( \pm 1.37)^{\mathrm{Aa}}$ & $22.18( \pm 0.98)^{\mathrm{Bl}}$ \\
\hline BRS 257 & $6.33( \pm 0.13)^{\mathrm{Aa}}$ & $5.44( \pm 0.2 \mathrm{~A})^{\mathrm{b}}$ & $36.43( \pm 0.51)^{\mathrm{Ab}}$ & $44.63( \pm 0.29)^{\mathrm{Ca}}$ & $22.90( \pm 0.30)^{\mathrm{Ab}}$ & $24.06( \pm 0.73)^{\mathrm{A}}$ \\
\hline BRS 267 & $6.35( \pm 0.10)^{\mathrm{Aa}}$ & $5.42( \pm 0.2)^{\mathrm{Ab}}$ & $36.69( \pm 1.13)^{\mathrm{Ab}}$ & $46.40( \pm 0.39)^{\mathrm{Ba}}$ & $23.94( \pm 0.92)^{\mathrm{Aa}}$ & $21.35( \pm 0.28)^{\mathrm{BL}}$ \\
\hline Mean & $6.13^{\mathrm{a}}$ & $5.04^{\mathrm{b}}$ & $36.16^{\mathrm{b}}$ & $43.16^{\mathrm{a}}$ & $23.20^{\mathrm{a}}$ & $22.13^{\mathrm{b}}$ \\
\hline
\end{tabular}

Same capital letters in the columns and same small letters in the lines for each group of compounds are not significantly different by Tukey test at $\mathrm{P} \leq 0.05$. 
than the 5\% described by Liu (1997). For tempeh, the average ash value was $5.04 \%$, similar to that reported by Vaidehi and Rathnamani (1990), 5.2\%.

Phytoestrogens are important compounds in nutrition and health due to their association with reduced incidence of some chronic diseases. Among these compounds, isoflavones present a non-steroidal structure that makes them function as estrogens in biological systems. These compounds act as antioxidants, enzymatic inhibitors, anti-inflammatories, and antimicrobials that affect several biochemical and physiological processes (SETCHELL, 1998; AGUIAR, 2002).

Isoflavones are affected by different processing techniques (COWARD et al. 1998; CARRÃO-PANIZZI; GOÉS-FAVONI; KIKUCHI, 2004), and changes in chemical composition modifying the isoflavones forms (glycosides, malonyl and aglycones) are common (AGUIAR, 2002). Isoflavones are also highly influenced by genetic variability and environmental conditions (CARRÃO-PANIZZI et al., 2009b).

Observing the overall content of isoflavone, the concentration was reduced in tempehs as compared to those of the grains. Nakashima et al. (2005) also observed reduction in isoflavone content in tempeh, and Haron et al. (2009) reported $43 \%$ reduction in total isoflavone in raw tempeh compared to that of fried isoflavone.

In tempeh preparation, grain soaking, dehulling, and cooking can result in loss of isoflavones. In general, dehulling does not cause significant losses of isoflavones because soybean hulls do not present isoflavones. However, isoflavone loss increase when dehulled grains are cooked (MURPHY, 1982).

The isoflavone malonyl forms are unstable at high temperatures and are converted to their respective $\beta$-glycoside forms (CARRÃO-PANIZZI; SIMÃO; KIKUCHI, 2003; CARRÃO-PANIZZI; GOÉS-FAVONI; KIKUCHI, 2004). In tempeh processing, soybean grains presented a significant reduction in the isoflavone malonyl forms after cooking (Table 2).

A reduction in the malonyl forms of about $43 \%$ on average (Table 2) was observed for the tempehs prepared with all cultivars, except for cultivar BRS 232, which presented a lower content of these compounds. Cultivar BRS 232 had the lowest amount of total isoflavones in the grains and tempeh (Table 2). Isoflavones $\beta$-glycosides in soybean grains were also significantly low (35.98 mg. $100 \mathrm{~g}^{-1}$ ), which made the tempeh prepared with this cultivar to present the lowest value $\left(22.27 \mathrm{mg} .100 \mathrm{~g}^{-1}\right)$ of these isoflavone forms (Table 2).

Total isoflavone content expressed as aglycons in the grains and tempehs prepared with grains of soybean cultivars BRS 216 , BRS 232, BRS 257, and BRS 267 are presented in Table 2. Grains of the cultivar BRS 257 presented the highest concentration of total de isoflavones (200.24 mg.100 g-1), and cultivar BRS 232 presented the lowest content $\left(89.63 \mathrm{mg} .100 \mathrm{~g}^{-1}\right)$. The same tendency was observed for tempeh prepared with cultivar BRS 257 (176.72 mg.100 g $\mathrm{g}^{-1}$ ) and cultivar BRS 232 (86.41 mg. $100 \mathrm{~g}^{-1}$ ). Analyzing the overall data of total isoflavone content, it can be observed that isoflavone concentration was reduced in tempeh as compared with the grains.

During tempeh fermentation, the glycoside forms are reduced, while the aglycon forms increases (COWARD et al., 1998). Fermentation or moisture activates the $\beta$-glycosidase enzyme causing hydrolyze of isoflavone glycosides forming the aglycon isoflavones (MATSUURA; OBATA, 1993). Concentrations of isoflavone aglycons in fermented soybean foods (natto, misô, shoyu and tempeh) are higher when compared with those of non-fermented foods (PARK et al., 2001).

In general, it has been observed that isoflavone aglycons are not formed in fresh harvested soybean grains (CARRÃOPANIZZI; SIMÃO; KIKUCHI, 2003). It is assumed that seeds should have some damage to favor water absorption giving conditions for $\beta$-glycosidades to catalyze aglycons formation.

The results presented in Table 2 showed reduced content of aglycon isoflavones in grains as compared with tempeh. Except for cultivar BRS 257, which presented an increase of about four times the aglycon content in tempeh; in all the other cultivars, the aglycon content increased by twofold. Cultivar BRS 232 presented the lowest content of aglycons in both tempeh and the grains (Table 2). According to Liu (1997), soybean fermented foods contain high content of aglycons, while non-fermented foods have mostly the conjugated forms.

Table 2. Malonylglycosides, $\beta$-glycosides, aglycons, and total isoflavones expressed as aglycon equivalents $\left(\mathrm{mg} .100 \mathrm{~g}^{-1}\right)( \pm \mathrm{SD})$ in soybean grains of cultivars specially developed for human consumption and in tempehs prepared with these cultivars.

\begin{tabular}{lcccc}
\hline \multicolumn{1}{c}{ Grains } & Malonylglycosides & $\beta$-Glycosides & Aglycons & Total isoflavones \\
\hline BRS 216 & $91.85( \pm 0.30)^{\mathrm{a}}$ & $72.50( \pm 0.12)^{\mathrm{b}}$ & $26.74( \pm 0.33)^{\mathrm{a}}$ & $191.09( \pm 0.32)^{\mathrm{ab}}$ \\
BRS 232 & $38.64( \pm 0.41)^{\mathrm{c}}$ & $35.98( \pm 0.32)^{\mathrm{c}}$ & $15.01( \pm 0.42)^{\mathrm{c}}$ & $89.63( \pm 0.32)^{\mathrm{c}}$ \\
BRS 257 & $81.76( \pm 0.53)^{\mathrm{b}}$ & $95.70( \pm 0.53)^{\mathrm{a}}$ & $22.77( \pm 0.51)^{\mathrm{b}}$ & $200.24( \pm 0.51)^{\mathrm{a}}$ \\
BRS 267 & $86.56( \pm 0.44)^{\mathrm{b}}$ & $73.96( \pm 0.96)^{\mathrm{b}}$ & $21.44( \pm 0.12)^{\mathrm{b}}$ & $181.96( \pm 0.73)^{\mathrm{b}}$ \\
$\quad$ & & & \\
Tempehs & & $30.01( \pm 0.12)^{\mathrm{b}}$ & $45.58( \pm 0.16)^{\mathrm{b}}$ & $123.91( \pm 0.12)^{\mathrm{b}}$ \\
BRS 216 & $48.32( \pm 0.21)^{\mathrm{a}}$ & $22.27( \pm 0.52)^{\mathrm{c}}$ & $27.22( \pm 0.24)^{\mathrm{c}}$ & $86.41( \pm 0.41)^{\mathrm{c}}$ \\
BRS 232 & $36.91( \pm 0.42)^{\mathrm{b}}$ & $55.50( \pm 0.49)^{\mathrm{a}}$ & $82.72( \pm 0.51)^{\mathrm{a}}$ & $176.72( \pm 0.52)^{\mathrm{a}}$ \\
BRS 257 & $38.51( \pm 0.33)^{\mathrm{b}}$ & $52.93( \pm 0.33)^{\mathrm{a}}$ & $40.49( \pm 0.42)^{\mathrm{b}}$ & $119.93( \pm 0.43)^{\mathrm{b}}$ \\
BRS 267 & $26.51( \pm 0.52)^{\mathrm{c}}$ & &
\end{tabular}

Same letters for grains and for tempeh in the columns for each group of compounds are not significantly different by Tukey test at $\mathrm{P} \leq 0.05$. 
Kunitz trypsin inhibitor (g.100 g $\left.{ }^{-1}\right)$

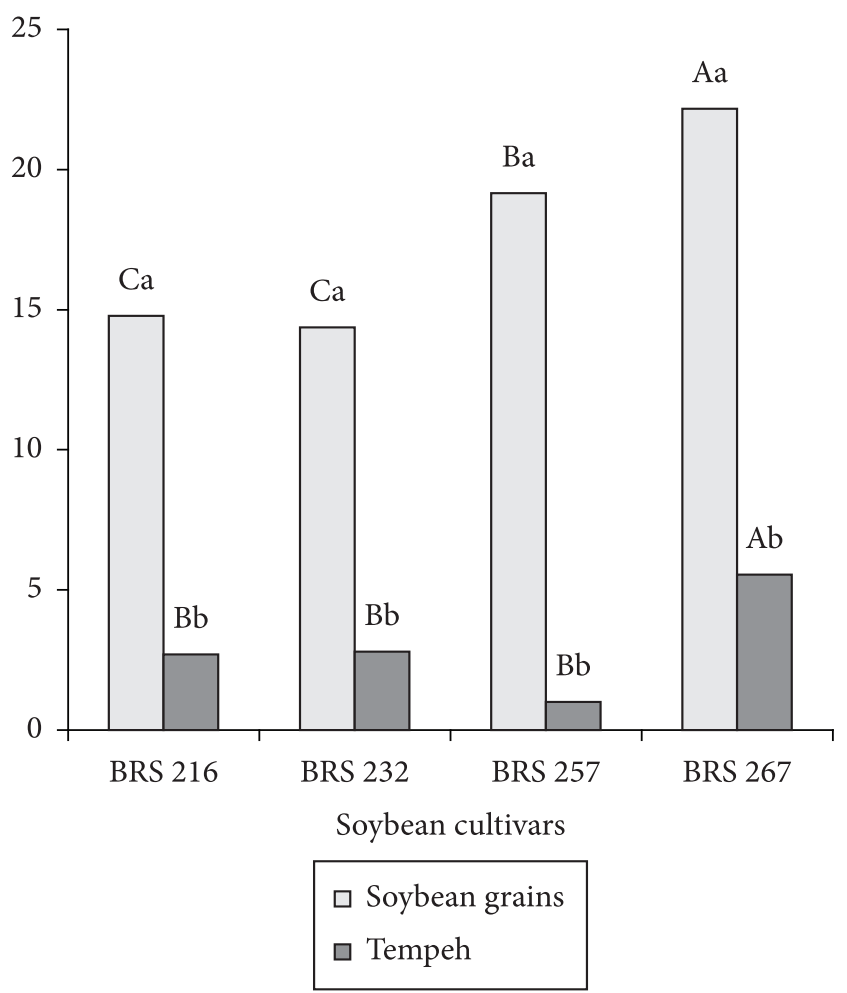

Figure 1. Kunitz trypsin inhibitor (mg. $\left.\mathrm{g}^{-1}\right)$ in soybean grains and tempeh prepared with different cultivars specially developed for human consumption. (Same capital letters among cultivars and small letters between grains and tempeh are not significant different by Tukey test at $\mathrm{P} \leq 0.05)$.

The content of Kunitz trypsin inhibitor was remarkable reduced in tempeh (Figure 1). Thermal treatments reduced about $80 \%$ of the trypsin inhibitor activity in the soybean grains (MANDARINO, 2010). In the present study, it was observed an overall reduction of $83 \%$, with some differences among the cultivars. Although this compound presents similar trend for all cultivars, the lowest content observed was in the tempeh prepared with cultivar BRS 257 (1.01 mg.100 g $\mathrm{g}^{-1}$ ). Cooking, soaking, and dehulling soybean reduced $82.2 \%$ of trypsin inhibitor (EGOUNLETY; AWORH, 2003),

Phytic acid has been reported to interfere with absorptions of mineral, especially zinc. However, phytic acid can also reduce the risk of kidney stone formation and heart disease, and it can act as anticancer agent by inhibiting the formation of endothelial cells (VUCENIK; SHAMSUDDIN, 2003).

Soybean grains contain about $1.0 \mathrm{~g} .100 \mathrm{~g}^{-1}$ to $2.30 \mathrm{~g} .100 \mathrm{~g}^{-1}$ of phytic acid (ANDERSON; WOLF, 1995). Fermentation processing mobilizes phytates by the action of phytase enzyme reducing phytic acid content (MANDARINO, 2010). Phytic acid in tempeh is in the range of $0.69 \mathrm{~g} .100^{-1} \mathrm{~g}$ to $0.96 \mathrm{~g} .100 \mathrm{~g}^{-1}$ (ANDERSON; WOLF, 1995). Egounlety and Aworh (2003) reported phytic acid reduction of $30 \%$ in tempeh fermentation for 36 hours. In the present study, differences for phytic acid content among cultivars were observed in grains and in tempehs (Figure 2). However, the decrease in this compound
Phytic acid (g.100 g $\mathrm{g}^{-1}$

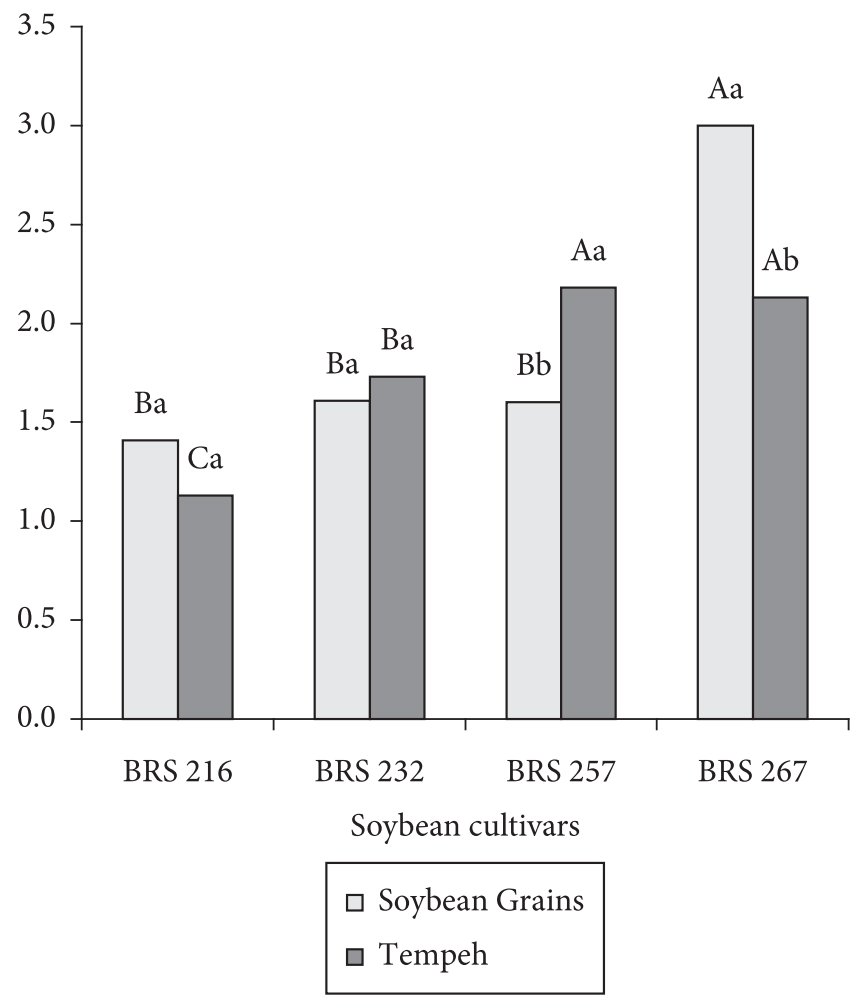

Figure 2. Phytic acid content (g.100 g $\mathrm{g}^{-1}$ ) in soybean grains and in tempeh prepared with different cultivars specially developed for human consumption. (Same capital letters for cultivars and same small letters for each product are not significantly different by Tukey test at $\mathrm{P} \leq 0.05$ ).

was observed only for cultivars BRS 216 and BRS 267. Cultivar BRS 267, which presented the highest content of phytic acid in the grains had a significant reduction in phytic acid in tempeh (Figure 2). Conditions for phytase activity ( $\mathrm{pH}$ or temperature), which were not measured; it is supposed that they were not ideal for reducing phytic acid in cultivars BRS 232 and BRS 257.

Tempeh prepared with soybean cultivars with high content of protein and isoflavone aglycons can be a good source of high nutritive food. Among the analyzed cultivars, BRS 216, which presents the highest content of protein and isoflavones, could be a good raw material for tempeh production. Trypsin inhibitor was similar to what has been observed for other soybean products, which means that trypsin inhibitor is reduced with thermal treatment. Phytic acid, however, presented different performance among the cultivars.

\section{Conclusion}

Tempeh prepared with soybean cultivars especially developed for human consumption, BRS 216, BRS 232, BRS 257, and BRS 267, presented different chemical composition. This traditional food from Indonesia with high nutritive value and biological functions can be directly consumed or used as raw-material (ingredient) for the preparation of other foods for Brazilians. 


\section{References}

AGUIAR, C. L. Isoflavonas de soja e propriedades biológicas. Boletim do CEPPA, v. 20, n. 2, p. 323-334, 2002.

ANDERSON, R. L.; WOLF, W. J. Compositional changesin trypsin inhibitorw, phytic acid, saponins and isoflavones related to soybean processing. Journal of Nutrition, v. 126, p. 581S-588S, 1995.

BERHOW, M. A. Modern analytical techniques for flavonoid determination. In: BUSLIG, B. S.; MANTHEY, J. A. (Eds.). Flavonoids in the living cell. New York: Klusher Academic, 2002. p. 61-76.

BORDIGNON, J. R.; SILVA, A. K.; CARRÃO-PANIZZI, M. C.; Phytic acid content in Brazilian soybean cultivars. In: INTERNATIONAL SOYBEAN PROCESSING AND UTILIZATION CONFERENCE - ISPUC, 3., 2000, Tsukuba. Proceedings... Tsukuba: The Japanese Society for Food Science and Technology, 2000. p. 97-98.

BRASIL. Ministério da Saúde. Instituto Adolfo Lutz. Normas analíticas do Instituto Adolfo Lutz: métodos químicos e físicos para análise de alimentos. 4. ed. São Paulo, 2005. p. 83-158.

CARRÃO-PANIZZI, M. C.; BORDINGNON, J. R. Activity of betaglucosidase and levels of isoflavone glycosides in soybean cultivars affected by environment. Pesquisa Agropecuária Brasileira, v. 35, n. 5, p. 873-878, 2000. http://dx.doi.org/10.1590/S0100204X2000000500002

CARRÃO-PANIZZI, M. C.; FAVONI, S. P. G.; KIKUCHI, A. Extraction time for isoflavone determination. Brazilian Archives of Biology and Technology, v. 45, n. 4, p. 515-518, 2002. http://dx.doi. org/10.1590/S1516-89132002000600015

CARRÃO-PANIZZI, M. C.; SIMÃO, A. S.; KIKUCHI, A. Efeitos de genótipos, ambientes e de tratamentos hidrotérmicos na concentração de isoflavonas agliconas em grãos de soja. Pesquisa Agropecuária Brasileira, v. 38, n. 8, p. 897-902, 2003.

CARRÃO-PANIZZI, M. C.; GOÉS-FAVONI, S. P.; KIKUCHI, A. Hydrothermal treatments in the development of isoflavone aglycones in soybean (Glycine $\max$ (L.) Merrill) grains. Brazilian Archives of Biology and Technology, v. 47, n. 2, p. 225-232, 2004.

CARRÃO-PANIZZI, M. C. Breeding specialty soybean cultivars for processing and value-added utilization at Embrapa in Brazil. In: WORLD SOYBEAN RESEARCH CONFERENCE, 8., 2009a, Beijing. Proceedings... Beijing: Chinese Academy of Agricultural Sciences; Institute of Crop Science, 2009. WSRC 2009. 1 CD-ROM.

CARRÃO-PANIZZI, M. C. et al. Enviromental and genetic variation of isoflavones content of soybean seeds grown in Brazil. Pesquisa Agropecuária Brasileira, v. 44, n. 11, p. 1444-1451, 2009b. http:// dx.doi.org/10.1590/S0100-204X2009001100011

COWARD, L. et al. Chemical modification of isoflavones in soyfoods during cooking and processing. American Journal of Clinical Nutrition, v. 68, n. 6, p. 1486S-1491S, 1998. Supplement.

EGOUNLETY, M.; AWORH, O. C. Effects of soaking, dehulling, cooking and fermentation with Rhizopus oligosporus on the oligosaccharides, trypsin inhibitor, phytic acid and tannins of soybean (Glycine max Merr.), cowpea (Vigna unguiculata L. Walp) and groundbean (macrotyloma geocarpa Harms). Journal Food Engineering, v. 5, p. 249-254, 2003. http://dx.doi.org/10.1016/ S0260-8774(02)00262-5

FERREIRA, M. P. et al. Changes in the isoflavone profile and in the chemical composition of tempeh during processing and refrigeration. Pesquisa Agropecuária Brasileira, v. 46, n. 11, p. 1555-1561, 2011. http://dx.doi.org/10.1590/S0100-204X2011001100018
HAMERSTRAND, G. E.; BLACK, L. T.; GLOVER, J. D. Trypsin inhibitors in soy products: modification of the standard analytical procedure. Cereal Chemistry, v. 51, n. 1, p. 42-45, 1981.

HARON, H. et al. Daidzein and genistein contents in tempeh and selected soy products. Food Chemistry, v. 115, p. 1350-1356, 2009. http://dx.doi.org/10.1016/j.foodchem.2009.01.053

HERMANA, M.; MAHMUD, M.; KARYADI, D. Composition and nutritional value of tempe: its role in the improvement of the nutritional value of food. In: AGRANOFF, J. (Ed.). The complete handbook of tempeh: the unique fermented soyfood of Indonesia. 2nd ed. Singapure: American Soybean Association, Liat Towers, 2001. p. 27-32.

KAKADE, M. et al. Determination of Trypsin inhibitor activity of soy products: A collaborative analysis of an improved procedure. Cereal Chemistry, v. 51, p. 376-383, 1974.

KARYADI, D. The development of tempeh across five continents. In: AGRANOFF, J. (ed.) The complete handbook of tempeh: the unique fermented soyfood of Indonesia. 2nd ed. Singapure: American Soybean Association, Liat Towers, 2001. p. 21-25.

KLUMP, S. P. et al. Determination of isoflavones in soy and selected foods containing soy by extraction saponification, and liquid chromatography: collaborative study. Journal of The Association of Official Analytical Chemists International, v. 84, n. 6, p. 1865 1883, 2001.

LATTA, M.; ESKIN, M. A simple and rapid method for phytate determination. Journal of Agricultural and Food Chemistry, v. 28, n. 6, p. 1313-1315, 1980. http://dx.doi.org/10.1021/jf60232a049

LEITAO, M. F. F.; MENEZES, T. J. B.; TANGO, J. S. Produção de tempeh, produto fermentado de soja. Coletânea do Instituto de Tecnologia de alimentos, v. 2, p. 333-339, 1967.

LIU, K. Soybeans chemistry technology and utilization. New York: Chapman and Hall, 1997. p. 260-273.

MANDARINO, J. M. G. Compostos antinutricionais da soja: caracterização e propriedades funcionais. In: COSTA, N. M. B.; ROSA, C. O. B. (Eds.). Alimentos funcionais: componentes bioativos e efeitos. Rio de Janeiro: Rubio, 2010. p.177- 192.

MATSUURA, M.; OBATA, A. Beta-glucosidases from soybean hydrolyse daidzin and genistin. Journal of Food Science, v. 58, n. 1, p. 144-147, 1993.

MURPHY, P. A. Phytoestrogen content of processed soybean product. Food Technology, v. 36, p. 60-64, 1982.

NAKASHIMA, N. et al. Analysis of isoflavone content in tempeh, a fermented soybean, and preparation of a new isoflavone-enriched tempeh. Journal of Bioscience and Bioengineering, v. 100, n. 6, p. 685-687, 2005. http://dx.doi.org/10.1263/jbb.100.685

NOUT, M. J. R.; KIERS, J. L. Tempeh as a functional food. In: WORLD SOYBEAN RESEARCH CONFERENCE, 7.; INTERNATIONAL SOYBEAN PROCESSING AND UTILIZATION CONFERENCE, 4.; CONGRESSO BRASILEIRO DE SOJA, 3., 2004, Foz do Iguaçu. Abstracts of contributed papers and posters... Londrina: Embrapa Soybean, 2004. p. 708-713. (Embrapa Soja. Documentos, n. 228). Editado por Flávio Moscardi, Clara Beatriz Hoffmann-Campo, Odilon Ferreira Saraiva, Paulo Roberto Galerani, Francisco Carlos Krzyzanowski, Mercedes Concordia Carrão-Panizzi.

PARK, Y. K. et al. Avaliação do teor de isoflavonas em soja brasileira. Ciência e Tecnologia de Alimentos, v. 3, n. 3, p. 156-160, 2001. http://dx.doi.org/10.1080/11358120109487723

PRIDE, C. Tempeh cookery. Summertown: The book Publishing Co, 1984. 127 p. 
STATISTICAL ANALISYS SYSTEM INSTITUTE - SAS. SAS user's guide: version 8.2. Cary: SAS Institute, 2001.

SETCHELL, K. D. Phytoestrogens: the biochemistry, physiology, and implications for human health of soy isoflavones. American Journal Clinical of Nutrition, v. 134, n. 6, p. 1333S-1343S, 1998.

SUDGIBIA, I. Tempeh in the management of infant diarrhea in Indonesia. In: AGRANOFF, J. (Ed.). The complete handbook of tempeh: the unique fermented soyfood of Indonesia. 2. ed. Singapure: American Soybean Association, Liat Towers, 2001. p. 23-40.

TONGTONG, S. et al. Soy isoflavone analysis: quality control and a new internal standard. American Journal of Clinical Nutrition, v. 68, p. 1474S-1479S, 1998.

VAIDEHI, M. P.; RATHNAMANI, A. The shelf-life of soy-sunflower tempeh and its acceptability to Indian children. Food Nutrition Bulletin, v. 12, n. 1, p. 53-56, 1990.
VILLARES, A. et al. Content and profile of isoflavones in soy-based foods as function of the production process. Food Bioprocess technology, v. 4, p. 27-38, 2011. http://dx.doi.org/10.1007/s11947009-0311-y

VUCENIK I.; SHAMSUDDIN, A. M. Cancer inhibition by inositol hexaphosphate (IP6) and inositol: from laboratory to clinic. Journal of Nutrition, v. 133, p. 3778S-3784S, 2003.

WANG, H. Uses of soybeans as food in the west with emphasis on tofu and tempeh. Plant Proteins, p. 45-60, 1986.

WEI, L. S. Domestic soybean consumption in Asia. In: TANTEERATARM, K. (Ed.). Soybean Processing for foood uses. Urbana-Champaign: University of Illinois, 1991. p. 162-183.

ZONTA, E. P.; MACHADO, A. A.; SILVEIRA JÚNIOR, P. Sistema de análise estatística. Pelotas: UFPEL, 1982. 63 p. 